\title{
STORY CREATION AND THE IMPACT OF TRAVEL JOURNALISTS ON DESTINATION BRANDS
}

\author{
Joao FREIRE* \\ Universidade Europeia, IPAM, e-mail: joao.freire@universidadeeuropeia.pt \\ Rita CURVELO \\ Universidade Católica Portuguesa, FCH, e-mail: ritacurvelo@ucp.pt
}

\begin{abstract}
Citation: Freire, J., \& Curvelo, R. (2021). STORY CREATION AND THE IMPACT OF TRAVEL JOURNALISTS ON DESTINATION BRANDS. GeoJournal of Tourism and Geosites, 37(3), 972-980. https://doi.org/10.30892/gtg.37332-734
\end{abstract}

\begin{abstract}
The main objective of this article is to present an insight into the process of story creation in the travel section of British newspapers. The research presented focuses on this specific area of written press in order to understand how stories are created and how destination brand managers can use and control this source of information to build brand image. In order to understand how journalists create their stories the authors conducted a qualitative research with six travel journalists. Because of the exploratory nature of this research, it was decided that the best method of data collection was in-depth interviews. Although the aim of the travel section is to inform readers, the nature of its written stories differs from the newspaper's other articles. In fact, reports published in the travel section tend to be positive and boast an optimistic outlook about places and leisure activities. Two main reasons may explain why this happens: first, the reason why a person reads the travel section; second, the symbiotic relationship between the press and travel or leisure organisations. These aspects influence the nature of the published stories and impact on how journalists write their articles. Despite the relevance of travel journalism, research on the topic is scant. The process of creating a story is poorly understood and therefore difficult for DMOs to manage this source of image creation
\end{abstract}

Key words: destination branding, DMOs, journalists, newspapers, travel section, image creation

$* * * * * *$

\section{INTRODUCTION}

Tourism is one of the major industries in the world (Cooper and Hall, 2008; Ninemeier and Perdue, 2005). In 2019 Tourism represented $1.3 \%$ of the Global GDP and 330 million jobs or 1 in 10 jobs around the world (World Travel and Tourism Council, 2019). In 2019, the travel and tourism sector grew 3.5\%. This is significant, considering that the global economy grew only 2.5\% during the same year (World Travel and Tourism Council, 2019). Travel disruptions in 2020 because of COVID-19 have demonstrated the relevance of tourism in the global economy. It is estimated that the pandemic put between 100 million and 120 million jobs in jeopardy and had a US\$2 trillion impact on global GDP in 2020 (UNWTO, 2021). Tourism is an important industry for almost all countries, contributing to exports, generating taxes and creating jobs (Blanke and Chiesa, 2013). The vital economic role of tourism in countless places justifies the growing interest in this issue, in particular by politicians. Politicians are now expected to invest and to develop strategies that increase the attractiveness of their places (Gertner and Freire, 2018; Pike et al., 2019). Therefore, politicians from countries, regions and cities are now using marketing tools such as branding to make their destinations more competitive. It can be said that the policymakers of a place are now sensitive to the issue of branding and are actively trying to apply the concept to their places (Anholt, 2014; Braun, 2012; Freire and Gertner, 2021; Zenker et al., 2013). It is in this context that places became destination brands, and organizations such as National Tourism Organizations (NTOs) or Regional Organizations (RTOs) at the regional level were set up (Pike and Page, 2014). NTOs and RTOs are organizations that are better described as being Destination Marketing Organizations (DMOs) (Pike and Page, 2014). DMOs are organizations that manage tourism within a certain place and have many tasks (Pike and Page, 2014). One of the most important is to develop a deep understanding on why and how tourists decide where to spend their holidays (Pike et al., 2019). It is vital to understand tourists so that places can develop strategies to become more attractive (Pike et al., 2019). An important factor to increase attractiveness is the development of a positive destination image (Pike et al., 2019). As a result, an important role for DMOs is to develop strategies that create and enhance positive images (Pike et al., 2019). To do this DMOs must understand the concept of image formation.

\section{Image formation}

It has been suggested that the nature of destination image formation is the result of the interaction between several elements and factors on a continuum of a sequence stage (Gallarza et al., 2002; Gartner, 1994; Gunn, 1988). This is in line with Reynolds's (1965) argument describing image formation as the development of a mental construct based on perceptions that emerge from a flood of information. It is recognised that information used to evaluate destinations emanates from two types of sources, formal (the commercial environment) and informal (the social environment) (Munro

\footnotetext{
* Corresponding author
} 
and Richards, 2011). Formal information can be characterised as originating from traditional sources such as travel agents, travel-guides, books, TV, specialised magazines (Echtner and Ritchie, 1991) as well as, and more importantly, from digital sources such as corporate blogs, a destination's own social networking platform, pages on Facebook and websites (Florek, 2011; Munro and Richards, 2011; Oliveira and Panyik, 2015; Page, 2009). The informal or organic information source can be characterised as recommendations and impressions from friends, family, acquaintances or other customers who have some kind of knowledge or experience with the chosen destination (Gunn, 1988; Munro and Richards, 2011). This last source of informal information increased dramatically with the Web 2.0 or social media, which is credited as contributing to an "unprecedented customer empowerment" (Constantinides and Fountain, 2008: 231).

Changes in technology have considerably increased the sources of information (Moutinho et al., 2013; Munro and Richards, 2011; Oliveira and Panyik, 2015). Cocking refers to the "emergence of hybridized forms of travel journalism" (Cocking, 2020:1), since there is now an extensive array of online channels available such as blogs, social media platforms and websites that are important sources of information and image creation (Constantinides and Fountain, 2008; Florek, 2011; Moutinho et al., 2013; Munro and Richards, 2011; Oliveira and Panyik, 2015; Page, 2009).

The division of sources of information, based on the assumption that they have a different nature, is pertinent because it acknowledges that image is partly controlled by a different sort of organisation (Gartner and Bachri, 1994; Pike and Page, 2013). This is a relevant argument supporting a destination brand management approach and the need for DMOs (Pike and Page, 2014). For example, tour operators and travel agents and hotels, through their catalogues (Schellhorn and Perkins, 2004), destination marketing organisations, through advertisements (Pan et al., 2017) and the media through their stories will influence destination brand image (Bieger and Laesser, 2004; Castelltort and Mäder, 2010; Pasquinelli and Trunfio, 2020). Media is a broad category, but in general refers to different types of communication, such as television, radio and newspaper. Media is considered relevant for destination brands since it is clear that it has an invested importance on creating destination brand awareness and diffusing destination brand values (Bieger and Laesser, 2004; Castelltort and Mäder, 2010; O'Shaughnessy and O'Shaughnessy, 2000). In the context of destination branding it is relevant to understand the media workings and its nature. Can media be a source of information controlled by destination brand managers? How can a destination brand manager control this source of information? In order to have a meaningful answer to these two questions, it is important to understand how the media works. The research presented in this article takes a restricted approach to the definition of media and focuses on written press, specifically targeting the travel section of British newspapers, with the objective of developing a better understanding on the process of story creation. By understanding how travel journalists create their stories it is possible to know if their articles can be managed by DMOs.

\section{LITERATURE REVIEW}

\section{Travel Journalism}

Considering the significant relevance of tourism and its impact on the economy, it is strange, as Hanusch (2010) has pointed out, the contempt with which travel journalism is often regarded. Hanusch noted that this field of study is viewed by many authors as a less serious genre, less related to journalism style and more linked to entertainment and lifestyle, stressing that it "has been criticised for being antithetical to public interest and watchdog notions of journalism" (Hanusch, 2010: 6234). He also stated that travel journalism is "still ridiculed by some as being unworthy of being associated with the term journalism" (Hanusch, 2012: 2). Moss, for example, states that "at best, this copy [travel journalism] often comes with few factual errors or sloppy observations (Moss, 2008: 36). Fürsich and Kavoori had already identified the disregard for this genre by finding that travel journalism was often considered a "frivolous topic, not worthy of serious research" (Fürsich and Kavoori, 2001: 152), probably because it has been associated by some scholars with leisure and pure entertainment and mass tourism without any social cultural focus of public interest (ibidem). Fürsich states that "genres that systematically ignore the social, economic or political problems of destinations (...) do not qualify as journalism" thus calling for a more serious and critical approach to travel journalism (Fürsich, 2003: 139). Despite its apparent "bad reputation”, Fürsich and Kavoori proposed arguments that justified a deeper study of travel journalism: the huge growth of the tourism industry; the evidence that leisure translates itself in a significant social practice; the fact that it is a fundamental aspect of the study of international communication and; finally, that its discourse is strongly affected or mediated by public relations (Fürsich and Kavoori, 2001: 70-71). The authors add that travel journalism is an important site for studying "the ideological dimensions of tourism, transcultural encounters and the ongoing dynamics of media globalization" stating that "travel journalism functions much like international news to provide both information and cultural frames for 'others' (2001: 153). They conclude that travel journalism has the ability to analyse and reveal different cultures and geographies (Fürsich and Kavoori, 2001).

Hanusch continues to assert that travel journalism plays "an increasingly significant role in the representation of foreign cultures" (...) underlining its "role in mediating foreign cultures, its market orientation, motivational aspects and its ethical standards", arguing that the travel journalist can be considered as a kind of "foreign correspondent" (Hanusch, 2010: 68). Duffy also underlines the importance of the travel journalist's role while connecting "the unfamiliar with the familiar" (Duffy, 2018: 863), bringing people from different regions of the globe closer together, or making the unknown visible. Following this line of thought, Santos views this type of journalist as a cultural intermediary or even a "social-cultural decoder", although sometimes forgetting to give local voices an adequate projection (Santos, 2004: 393-4). Pokazanyeva (2013) characterizes travel journalism as a genre that includes various fields of study such as "history, geography, culture, art, ethics, and philosophy", referring that "the field includes: travel writing; travel programming for television, radio and podcasting; documentary; and other forms and genres" (2013: 199). Belenguer (2002) shares a similar point of view when arguing that travel journalism is "specialized journalism, based on historical background, on the existence of numerous publishing 
platforms (magazines, documentaries or thematic channels), on the diversity of genres approach (from reports, chronicles and interviews to opinion columns), or even the professional specialization of its practitioners" (Belenguer, 2002: 114).

Despite being a journalistic genre written by professionals, some accuse travel journalism of a lack of transparency or credibility since journalists are often paid for their trips (McGaurr, 2013). McGaurr explains that due to the high price of travel, many journalists today, especially freelancers, would not be able to do their job if there were no so-called "visiting journalist programs or freebies" (McGaurr, 2013: 54). Santos also tackles this argument by noting that "travelling and reporting from distant lands costs a lot of money and few, if any, newspapers seem able to pay for every trip abroad needed to fill a 40-page travel supplement every week" (Santos, 2004: 73), drawing attention to the fact that sponsorships may weigh favourably at the time of writing the article. For this reason, the author argues that journalists should "always disclose the sponsorship information" (Santos, 2004: 74). This is not equivalent to maintain that freebies necessarily imply uncritical or $100 \%$ flattering reporting. It is intended to point out that, in the specific case of travel journalism, paid tours and accommodations are sometimes the only way travel journalists can publish their articles (Santos, 2004; McGaurr, 2013).

As Cocking (2017: 1349) supports, "travel journalism is by no means wholly uncritical or lacking in integrity - travel articles might sell us tourist experiences but it might also, for example, bring to our attention specific local cultural practices, or environmental, health or poverty initiatives". Perhaps for this reason, Pokazanyeva (2013: 201) holds that "travel journalism occupies a neutral position between commercial and independent journalism. The programs are not independent, but are also not purely commercial. Sponsoring interaction between channels and travel agencies is beneficial". Pokazanyeva underlines that "one of the main ethical objectives of travel journalism is to establish a balance between benefits from sponsorship and desire to represent the facts (Pokazanyeva, 2013:202).

For DMOs, with their PR agencies as facilitators, the alliance with journalists is highly beneficial as they see in their work the reputation, objectivity and independence they need to make their destinations more appealing. In this respect, it should be noted that advertising is becoming less and less effective compared to news articles. On the other hand, sponsors are now more interested investing in social media and its influencers, travel blogs and vlogs, as it is cheaper and the information circulates much faster (Pirolli, 2019). As Cocking states "advertising revenue, that so long brought financial security to print journalism, is now being reassigned to rapidly changing online media environment" (2020:1).

Thus, it is a win-win relationship, as some see their destinations promoted by reliable professionals and others are paid for their work. In fact, and as Dore and Crouch (2003:140) mention, "the VJPs [visiting journalist programs] have become decisive in the fate-promoting strategies of the tourism organizations of various governments around the world". In this context, the dialogue between PR's and travel journalists has come to be seen as "a trading or exchange relationship" (Lewis et al., 2008: 5). It is no secret that travel journalism work can be partly based "on pre-prepared public relations material produced by or for travel companies" (Hanusch, 2012a: 670), with the media assuming the role of intermediaries between the DMOs and the tourists. Journalists have the task of "gatekeepers" for the information provided by the DMOs and their PR agencies (Zerfass et al., 2016). Therefore, it can be difficult to distinguish between what is considered journalism and what constitutes business content.

The distinction between news or reporting about the destination and a promotional narrative of the same place isn't always clear (Hanusch, 2012a; Zerfass et al., 2016). As Rosenkranz recalls, "today, the journalistic field is undergoing a radical transformation of practice (...). As a result, formerly solid lines separating business and editorial departments, print and online publishing spaces, professional journalists and amateur content are blurring (Rosenkranz, 2015:1).

\section{METHODOLOGY}

Despite the relevance of travel journalism, research on the topic is scant (Pirolli, 2017). The process of creating a story is poorly understood and therefore difficult for DMOs to manage this source of image creation. In order to understand how journalists create their stories the authors conducted a qualitative research with six travel journalists. Because of the exploratory nature of this research, it was decided that the best method of data collection was in-depth interviews.

In-depth interviews as a data collection tool were preferred due to their inherent advantages, including their flexibility and exploratory nature (Patton, 1990; Shiner and Newburn, 1997). Although the in-depth interviews can be initially conducted with a pre-established logic, the interviewer is totally free to explore or clarify certain concepts that emerge or that were not totally understood. This tool gives the interviewer the freedom and flexibility to explore questions and concepts that may be relevant and unexpected (Patton, 1990). Moreover, in-depth interviews minimize the degree to which respondents have to express themselves in terms defined by the interviewers and encourages them to raise issues that are important to them (Shiner and Newburn, 1997). In-depth interviews are particularly appropriate in order to try to discover journalists' own meanings and interpretations. They are valuable instruments for clarifying concepts, understanding the existence of certain events, or opening doors to new research directions (Patton, 1990).

\section{Participants}

All of the journalists who took part in the research were contributors to UK national newspapers. Although all of the interviewees were journalists their characteristics and nature differed. Accordingly, one was the editor of the travel section for a UK national newspaper; another two were staff reporters and three others were freelancers, writing for British national newspapers. The authors identified the journalists by their contributions in leading UK national newspapers. Once identified, reporters were contacted and interviews were arranged. The interviews took on average between 45 minutes and 2 hours, and were recorded. Afterwards, the interviews were transcribed for analysis. The six interviews were conducted in different places in London, two were at the newspaper's offices and four in pubs/cafes. The location was important to 
ensure that the appropriate conditions were created for the interviewees to participate honestly and genuinely (Merriam, 1988). In order to get honest and sincere answers on how journalists wrote their stories, interviewers began the conversation similar to 'everyday talk'. This method follows Ezzy (2010) recommendations. Using the notion of 'everyday talk' as a method allowed the interviewee to become a questioner and therefore the flow of the interview and all the questions asked to interviewees do not necessarily have to be pre-figured or scripted but are rather produced in reaction to the here-and-now-talk (Rapley, 2001). Basically, the route to get the answers to the research questions is not linear, rather it has to be adaptive and dependent on the flow of the conversation. This allows interviewees to express themselves in terms defined by them and with minimum interference or impact from the interviewer (Shiner and Newburn, 1997).

After field data collection, the final step of the research starts - data analysis. Data analysis involves the organization of what has been seen, read or heard, so that the researcher can provide some understanding of what has been learned. When working with data, the author can create explanations, hypothesize, theorize and link stories to other stories. To accomplish this, it is necessary to classify, synthesize, examine patterns and interpret the data. Therefore, the primary role of the investigator will be to make sense of the data collected (Lincoln and Guba, 1985; Miles and Huberman, 1994; Strauss and Corbin, 1998). Miles and Huberman (1994) argued that data analysis should be examined using a model that assumes the interaction of three groups of concurrent activities: reduction, display of data, and conclusion drawing. Reducing data refers to the process of turning data into significant units that can be easily manipulated. It involves identifying common themes and aggregating them. Data display is central to the Miles and Huberman (1994) analysis model.

This should be done in a visual format, with the aim of presenting the data collected in a schematic manner. The analysis process is made up of the representation of information, which can be done using matrices for example. In this case the researchers used NVivo software to help reduce the data into themes. NVivo software is useful to organize and visualise the data and to help to draw conclusions. The conclusion comprises the third group of analysis activities, however, the findings start to emerge once the data begins to be organized and displayed.

The validity and plausibility of the data gathered was subjected to a systematic test. This was accomplished by asking a variety of external researchers to validate the organization of the data. But data analysis needs to be viewed as an interactive and cyclical process that simultaneously involves data collection, theory building and conclusions. Final conclusions were drawn once the analytical process was completed (Strauss and Corbin, 1998). For reasons of validity, the authors followed the instructions of Wolcott (1990) and included excerpts from the interviews in this article. Essentially, with quotes from participants the reader will be able to trace the findings from the data that generated them (AttrideStirling, 2001; Cho and Trent, 2006) and follows Wolcott's (1990:129) recommendation "let readers 'see' for themselves."

\section{RESULTS AND DISCUSSION}

Usually, newspapers are composed of several sections, each of them reporting on different topics, with tourism and travel news typically aggregated in a travel section. Although, the objective of the travel section is to inform readers, the nature of the written stories in this section is different from the rest of the newspaper as the stories tend to boast a positive outlook. Two main reasons for why this happens were identified and will be covered in part one of the findings. First, the nature of the travel section is influenced by the characteristics of the readers and, second, because of the symbiotic relation between the press and organisations linked to the travel and leisure industry. These aspects, which influence the nature of the published stories, will also impact on how journalists write their articles. Part two of the findings describes which forces influence and impact on the journalists' writing process. Part three builds on the previous two parts and concludes that a major aspect of these stories is the degree of originality. Thus, for travel journalists originality is key to getting their stories published.

\section{Stories: a Positive Outlook}

\subsection{Readers}

The travel section of a newspaper and the format it follows is different from the rest of the newspaper. The objective of this section is to inform readers about destinations and leisure activities. There is the general agreement among journalists that readers only want to read positive things in the travel section. The information in this section should be based on positive reviews, not negative ones, and providing readers with nice and pleasant reading material is the logic behind this section. It is understood that any negative incident experienced by the journalist in a destination will not be written about or exposed in this section. Journalist) That's right you normally don't read bad things about a destination ... because otherwise you would not bother to read it. You don't want to read disasters stories. There are sections that deals with sort of holidays from hell but they are normally kept apart, that's also with the TV programmes...holidays from hell. I think the reason you don't get this sort of horror stories, like: "this is the worst place I've ever visited" it's because people don't actually want to read that. People prefer to read something that they are attracted to.

Journalist) Everybody is fully aware that we do not have to give positive publicity to the destination. In fact, it has happened, being somewhere and not enjoyed it and asked the responsible - what's the point? Do you really want us to write a story saying that this is a "shit-hole"? We can do it, but it is not helping the destination and it is not helping our readers, because the point about reading the travel section is trying to give the idea about what the person might enjoy in a certain place. It wouldn't be pleasant to read a negative view. As stated above, there is a general agreement among journalists that the travel section should only contain positive reviews about destinations. Journalists defend this position and argue that readers are not interested in reading negative reviews of a destination. Clearly, there is another force conditioning the nature of the travel section. The travel section of newspapers is extremely dependent on DMOs, NTOs and other organizations operating in the travel and tourism industry such airline companies, hotels, and tour operators. 


\subsection{DMOs and other Travel and Tourism Organisations impact on stories}

The travel section of newspapers is dependent on organisations that operate in the travel and tourism industry. In fact, staffed journalists or freelancers are dependent on the help of these organisations to conduct their work. It is not financially viable for a newspaper to support the costs of the travel section without any kind of support from external organisations. Therefore, journalists and newspapers have to rely on the sponsorship of travel and tourism organisations to write their stories for the travel section. That being the case, journalists, who are dependent on travel and tourism organisations, do not have any incentive to write negative reviews about a destination. It is reasonable to assume that a reporter who writes a negative review about a destination might have some difficulties in the future getting financial support from the travel and tourism organisations. Therefore, both journalists and newspapers have a strong incentive to avoid conflicts with tourism industry organisations, implying that material written in a newspaper's travel section might be partially controlled.

Journalist) (...) I write independent but I use the facilities provided by them [DMOs] because otherwise you couldn't afford to do it. I think people realise that but ...they expect to be honest too. So it's a funny game because yes you are accepting facilities from the people you are writing about, in one sense your hands might be tied but depends on how you see it. At the same time you wouldn't be writing the article if those facilities were not available and the newspapers wouldn't be able to cover those pages. So there is a kind of symbiosis between the newspaper world, the travel pages, the tourism boards and travel companies and their alliances. For example, the XXXX gets... BA [British Airways] provides some of the flights, free flights every year with the expectation to appear in the travel section. So they feed on each other.

Interviewer) I thought that you could just fly with your own budget and you wouldn't be so dependent on external players.

Journalist) It would be really nice if that could happen but it is very, very difficult for that to happen. I don't know one newspaper or magazine that doesn't use help. Because if you wouldn't ask for help you couldn't make it worth it.

Journalist) (...) I also write travel articles for the national papers. I come up with an idea and propose it to the editors. Then I get support from tourist boards, which pay for my facilities and then off I go and write the story.

Journalist) (...) Sometimes they will not pay all, but they will pay some of it. But then, you put a package together, you know? For the journalist it has to be financially viable. If you have to pay a lot of expenses it's not worth going. So you've got to work quite hard to put...but normally you find that the tourist boards or tourist offices are keen to help. Because they know the value of space in a national newspaper, I mean against the cost of advertising. It's very cheap to pay the journalist, travel or accommodation cost so it's a good deal for them.

\section{Choosing a story to write about}

In order to understand how to manage this source of image creation, it is important to understand the process journalists follow to create and write an article. It is also relevant to understand their sources of information and inspiration. Their stories on destinations emerge from three forces that can work together or individually. These forces can be market-driven, personal-interest-driven or DMO-driven.

\subsection{Market driven}

Some journalists use tourism industry market trends as a source of information and inspiration for their stories. Moreover, newspaper editors will also take in consideration the profile of the newspaper's readers. There is careful editorial management in order to assure that the stories published are relevant for their readers. Therefore, what is written in the travel section can be dictated by fashion and market trends. Journalist) But also you look for trends in the industry as well. For instances if the ski season ends and in talking with travel agents you find out that there was a huge increase in bookings to North America then you might write something about North America. Interviewer) I guess you get a lot of invitations from too many destinations. How do you decide which destination you should go? Would you go to Costa del Sol?

Journalist) Probably not. You are trying to engage of what your readers would like. In the XXXX we have a committee of readers. They are 5000 readers that subscribe to the surveying XXXX and we ask questions and try to form an idea about our readers says. Market research shows that XXXX core audience is people 20 to 45 earning a decent amount of money, possibly without a lot of time in their hands, and quite adventure travellers looking for something different. So we probably show any trip that is more about that than 2 weeks on a beach in Turkey. Probably those kinds of trips is more the Daily Mirror that write those kind of stories so we need to go probably aspirational we might spend a week on this fantastic beach in Tahiti.

Journalist) But you've got to remember that you are writing to...there is a huge demand for adventure holidays, nonstandard, packaged holidays, so I mean I think this is a big growth area. I mean I went to the adventure travel show in Olympia early this year, which is worth being to, you know. I got an all range of brochure from there to follow up ideas. I think people want...they are fed up lying down on the beach, they want to go and do something, you know walking, hiking or golfing.

Interviewer) It seems that for some regions everything has been written. For instance Paris, what will you write about Paris?

Journalist) There are always articles about Paris, because Paris always attracts several types of people. I could write about new exhibitions. There's always interest in Paris so you can have always a new angle about Paris.

Some of the stories written by journalists are inspired by observing trends in the market, therefore they are market driven. Journalists observe the market trends and write about what readers wants to read. In this case places or activities that are seen as unfashionable might have difficulties getting coverage as opposed to others that are seen as fashionable.

\subsection{Personal interest}

Journalists often write about their own particular interests and hobbies. These stories are personal and are inspired by the journalist's specific interests. 
Interviewer) How do you come up with your ideas?

Journalist) There's no formula. It's just things that I am interested in and I care about. Obviously I read a lot, I travel quite a bit, and a lot of things I observe become ideas you know. So there's no simple route.

Journalist) I mean when I went to Australia for example I wrote three articles on different subjects including art and gardens but I didn't follow the tour that they offered. I chased what I wanted.

Interviewer) If you heard that a region or a country has a particularly good writer or other cultural icon. Do you think that affects how you perceive that place?

Journalist) Yes, absolutely. I mean, for example, one of the reasons I went to Mexico City a few years ago was to write about a sculptor who was working at producing the world's largest statue about a man in a horse that would be put on the border between America and Mexico. It was a story about a man doing something extraordinary. So those kinds of individuals, the people related to the story are very good.

It is also evident that the nature and content of the story is dependent on the affective relationship between the reporter and the destination. Journalists will dedicate more time and be more investigative towards destinations they like. In this case, they will be willing to invest time to find new angles and write about particular destinations.

Journalist) I will give you an example. I went to Japan in November to go, you know, hiking in the mountains in a small group, and I wrote about that to the XXXX. Those were some mountains near Kyoto and that was very interesting. But that was something I wanted to do because I'm very interested in Japan so I was looking for angles on Japan.

The personal interest of journalists and their emotional connection with destinations are relevant aspects on the process of story creation. This implies that DMOs should identify and target journalists who are more inclined to write about particular destinations and themes.

\subsection{Stories written and influenced by DMOs}

DMOs also have an impact on the stories published in the newspapers. This is only possible because newspapers and their journalists are dependent on the support of these organisations to conduct their business. Therefore, DMOs are the third route on the story creation.

Journalist) The third thing is probably stories that are promoted to you by tourist boards or by PR experts that work for the tourist boards. You tend to find two different ways to have that happening: first, the country or destination has their internal PR mechanism or they will have the external agency. When it comes to the PR agency they aren't usually as good or dedicated to a destination as they might have five competing destinations as their clients, so you get people not as dedicated. So normally if you talk with people from the destination it is a better method of approach you will have a better view. Sometimes you get the agency saying that they have a great story and in reality, they do not have any great story. It happens because normally that information is second hand, so by the time that is transmitted to you some of the meaning got lost.

Interviewer) There is a lot of people writing about travelling. I guess it must be difficult to write new stuff about destinations...

Journalist) A lot of people are covering, so yes, if something is well promoted, you'll find people pick up earlier on that and therefore you get a lot of people writing about the same thing, which is good from one point of view. I mean for example, take this idea of the next weekend Amsterdam canal garden. I just discovered that three newspapers are already covering it. Because their promotion PR has basically done a good job or the DMO, I'm not sure.

In certain situations DMOs are the source of information and inspiration, which implies that some of the stories published in the travel section are, in fact, directly controlled by these organisations.

Interviewer) What do you think about those trips? What is your experience?

Journalist) Well it is totally subjective. Some of the people that are working for the PR companies or NTOs are exjournalists, they know facts about the places and what is relevant to show in order to be published. But it depends. Sometimes I ask them if I can be excused from writing about a particular thing they are promoting. The answer depends. Sometimes will say that is fine other times they will say that we really need to write about that particular thing of the trip.

Stories published in newspapers emerge from three forces. They can originate from the journalist who is pursuing a personal interest, through observation of market trends or from DMOs that promote a particular event. However, a story will only be pursued if the journalist is attracted to the topic and will only be published if the editor thinks the readers will be interested in it. But the journalists still need the DMOs, who influence the story often in a positive and benign nature, to have the story commissioned. Therefore, the creation of a story is dependent on these three forces operating simultaneously.

\section{The need for having original stories}

As mentioned above, in order to have the story published the journalist not only needs the support from an DMO or other travel and tourism organisations. The journalist must also convince the editor of the travel section that the story is worthy of publication. One of the requirements imposed by editors is that the story is somehow original since editors are reluctant to publish stories that are considered unoriginal. Therefore, journalists must be sure that the story they are submitting to the newspaper is unique.

Journalist) Often I am asked by the editor if anybody else is covering a particular story. They like to think they have an exclusive. The problem of arranged press trips, where a number of journalists come from different newspapers or magazines to cover the same thing, is that, obviously the same story will appear on a number of publications. You see, somehow you have to satisfy newspapers desire to be exclusive...

One of the techniques used to guarantee originality in a story is to write from a personal perspective. 
Interviewer) Do you have to be original in terms of what you write? Every main newspaper has a travel section so I guess a lot of things have been written already...

Journalist) Yes, I suppose. But is up to the editor to make sure that what you are offering isn't the same as everybody else. They are looking for something very different, different point of views. I would give my point of view that is very individual because of whom I am. So...but the editor has to make sure that we are not reproducing the same story. Editors are very unhappy with the same possible piece, that's for all newspapers.

Therefore, travel journalists, as opposed to mainstream journalists, write about their own experiences and their stories tend to be self-centred.

Interviewer) In that case you reach a point that you do not write about a place in terms of nice beaches or nice landscape...you will have only articles about experience.

Journalist) Yes, very often the articles are written in the first person. I did this I went there so there's a story line to follow. I think sometimes it might be too much... but they [the editors] like it. For example there're a lot of people that take their children to this sort of...these experiences, there are a lot of people writing about these experiences with children. Because, the people that are aged 60 plus is a major sort of market for travel now. For that sort of market you could perhaps concentrate more on the history and the culture of the region.

Writing stories in the first person assures journalists that their stories have an original component. Thus, the relevance of the article's theme has more to do with the story behind the destination, not with the destination itself. This implies that each destination can have perpetual cover as long as it provides an original theme for story creation. The location itself becomes less relevant and the theme, or the story being pursuit, more relevant. Thus, everything is tailored to create an original story. This is easily achievable since articles in the travel section are stories, not news, and implies that there are infinite ways for a destination to make the pages of a newspaper's travel section.

\section{CONCLUSION}

As Bieger and Laesser (2004), Castelltort and Mäder (2010), Pasquinelli and Trunfio (2020) argue, the press has an important role on the destination image formation. It is essential to understand how journalists create their stories and how they can help shape and communicate facets of brand image. At the same time, it is important to understand that the image creation can also be partly controlled by DMOs. In fact, a symbiotic relationship between tourism organizations and newspapers was shown. The travel section of newspapers is only profitable if they are sponsored by travel and tourism organisations, such as airlines, hotels, etc., and organisations such as DMOs and NTOs. Newspapers are unable to bear the costs of the travel section if they do not have the assistance from these organisations. Therefore, the stories published in the travel section have unique characteristics compared to other sections of a newspaper. One characteristic is that travel stories tend to boast a positive outlook of occurrences. This is not only due to the interdependency between newspapers and travel/tourism organisations but also because of the nature and objective of the travel section. Readers of the travel section, journalists defend, only want to read positive stories. Important to note, however, is that journalists don't have an incentive to write negative reviews about a destination either. It's quite the opposite since the journalist's work is dependent on the people and places they write about. Therefore, even if journalists have a negative experience with a destination they have little incentive write about it. Another characteristic of travel stories is that they are often written in the first person.

They tend to be about the journalist's personal experience and that is partly due to the need of fulfilling a basic requirement imposed by the editors - the stories need to be original and different from what is being published in other newspapers. Thus, journalists write about their individual experiences to guarantee that what they are writing is original and unique. Journalists are always seeking new angles for writing new stories which means that a destination brand could potentially always have positive exposure and appear often in the travel section. To ensure a presence in travel sections, DMOs could create and recommend thematic stories to journalists. However, since originality is key, the material supplied by DMOs and PR agencies should be tailor-made for each journalist. Identifying and then targeting individual journalists with a certain theme or particular story is the most efficient way for having an article published in the travel section. This implies that DMOs should build databases to identify and target the journalists who are willing and interested in writing about a specific theme. In conclusion, when creating a story for a travel section of a newspaper there are three main sources: market trends, personal interest and DMOs. However, if the stories are to be published they must have two characteristics: a positive outlook and originality.

The process of story creation and subsequent publishing is the result of the journalist's inspiration but with market and editor restrictions (Figure 1).

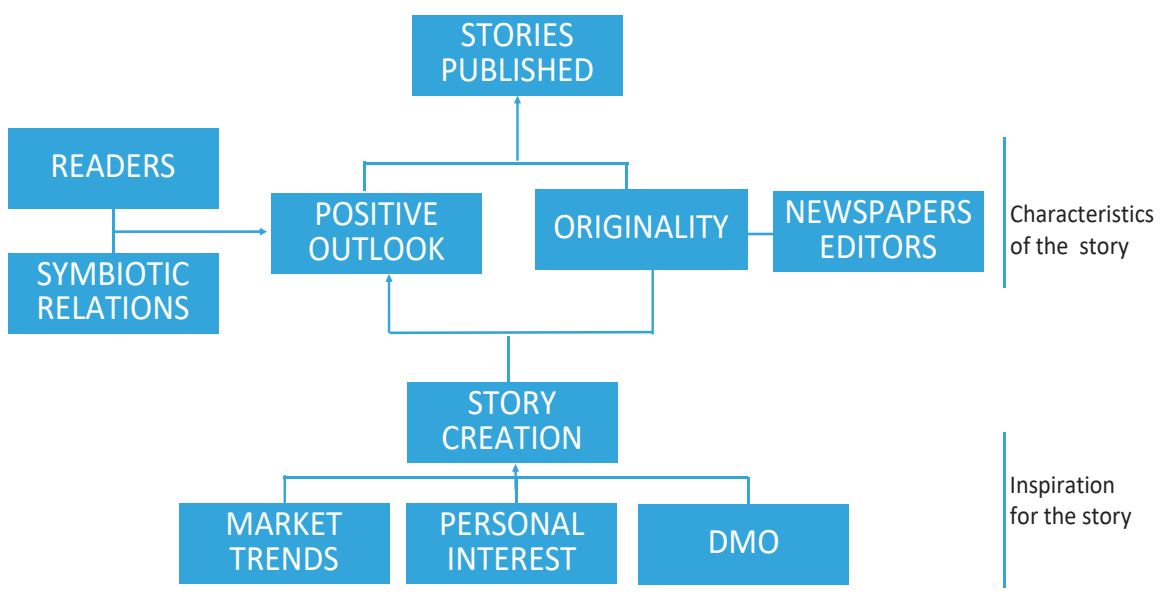

Figure 1 - The Travel News Publishing Process 
It should be noted, however, that the travel section of newspapers is not the only source of image creation. Other sources of information, like the organization's blogs, websites and social media platforms, are also relevant in shaping the destination's image (Florek, 2011; Moutinho et al., 2013; Munro and Richards, 2011; Oliveira and Panyik, 2015; Pirolli, 2019). Therefore, as Cocking underlines nowadays "tourism companies are seeing the potential in advertising and sponsoring online spaces" since "blogging platforms offer huge possibilities" (Cocking, 2020:1).

Having this reality in mind, it is critical for destinations to coordinate various sources of information to establish a common identity, which is only possible if destinations take a brand management perspective.

\section{REFERENCES}

Anholt, S. (2014). Afterword. Place Branding and Public Diplomacy, 10(2), 167-169. https://doi.org/10.1057/pb.2014.4

Anholt, S. (2007). Competitive identity: the new brand management for nations, cities and regions. Basingstoke: Palgrave MacMillan. https://doi.org/10.1057/palgrave.bm.2550086

Attride-Stirling, J. (2001). Thematic networks: an analytic tool for qualitative research. Qualitative research, 1(3), $385-405$. https://doi.org/10.1177/146879410100100307

Belenguer, M. (2002). Periodismo de viajes. Análisis de una especialización periodística, Sevilla, Comunicación Social.

Bieger, T., \& Laesser, C. (2004). Information sources for travel decision: Toward a source process model. Journal of Travel Research 42(4), 357-371. https://doi.org/10.1177/0047287504263030

Blanke, J., \& Chiesa, T. (2013). The Travel and Tourism Competitiveness Report 2013. In The World Economic Forum, assessed on January $10^{\text {th }}, 2020$. http://www3.weforum.org/docs/WEF_TT_Competitiveness_Report_2013.pdf

Braun, E. (2012). Putting city branding into practice. Journal of Brand Management, 19(4), 257-267. https://doi.org/10.1057/bm.2011.55

Castelltort, M., \& Mäder, G. (2010). Press media coverage effects on destinations-A Monetary Public Value (MPV) analysis. Tourism Management, 31(6), 724-738. https://doi.org/10.1016/j.tourman.2009.06.007

Cho, J., \& Trent, A. (2006). Validity in qualitative research revisited. Qualitative research,6(3), 319-340. https://doi.org/ $10.1177 / 1468794106065006$

Cocking, B. (2020). Travel Journalism and Travel Media: Identities, Places and Imaginings. London: Palgrave MacMillan. https://doi.org/10.1057/978-1-137-59908-7

Cocking, B. (2017). News Values Go on Holiday. Journalism Studies, 19(9), 1349-1365. https://doi.org/10.1080/1461670X.2016.1272066

Constantinides, E., \& Fountain, S.J. (2008). Web 2.0: Conceptual foundations and marketing issues. Journal of direct, data and digital marketing practice, 9(3), 231-244. https://doi.org/10.1057/palgrave.dddmp.4350098

Cooper, C., \& Hall, M. (2008). Contemporary tourism: An international approach. London: Butterworth Heinemann.

Dore, L., \& Crouch, G. (2003). Promoting destinations: An exploratory study of publicity programmes used by national tourism organisations. Journal of Vacation Marketing, 9 (2), 137-151. https://doi.org/10.1177/135676670300900203

Duffy, A. (2015). The road more travelled: how user-generated content can lead to homogenized travel journalism. Continuum, Journal of media and cultural studies, 29(6), 821-832. https://doi.org/10.1080/10304312.2015.1073686

Duffy, A. (2018). Wherever I Go, There You Are. The mobility/mooring paradigm in travel journalism. Journalism studies, 19 (6), $863-$ 880. https://doi.org/10.1080/1461670X.2016.1238317

Echtner, C.M., \& Ritchie, J.R. (1991). The measurement of destination image: an empirical assessment. Journal of Tourism Studies, 2(2), 2-12. https://doi.org/10.1177/004728759303100402

Ezzy, D. (2010). Qualitative interviewing as an embodied emotional performance. Qualitative Inquiry, 16(3), 163-170. https://doi.org/10.1177/1077800409351970

Florek, M. (2011). Online city branding. In City branding, 82-90, Palgrave Macmillan, London. https://doi.org/10.1057/9780230294790_10

Freire, J.R., \& Gertner, R.K. (2021). The relevance of food for the development of a destination brand. Place Branding and Public Diplomacy, 17(2), 193-204. https://doi.org/10.1057/s41254-020-00164-5

Fürsich, E. (2002). How can global journalists represent the 'other'? A critical assessment of the cultural studies concept for media practice. Journalism, 3, 57-84. https://doi.org/10.1177/146488490200300102

Fürsich, E. (2003). Between credibility and commodification: nonfiction Entertainment as a Global Media Genre. International Journal of cultural studies, 6 (2), 131-153. https://doi.org/10.1177/13678779030062001

Fürsich, E. (2012). Lifestyle journalism as popular journalism: Strategies for evaluating its public role. Journalism Practice, 6 (1), $12-$ 25. https://doi.org/10.1080/17512786.2011.622894

Fürsich, E., \& Kavoori, A. (2001). Mapping a critical framework for the study of travel journalism. International Journal of Cultural Studies, 4 (2), 149-171. https://doi.org/10.1177/136787790100400202

Gallarza, M.G., Saura, I.G., \& García, H.C. (2002). Destination image: Towards a conceptual framework. Annals of Tourism Research, 29(1), 56-78. https://doi.org/10.1016/S0160-7383(01)00031-7

Gartner, W.C. (1994). Image formation process. Journal of Travel and Tourism Marketing, 2(2-3), 191-216. https://doi.org/10.1300/J073v02n02_12

Gartner, W.C., \& Bachri, T. (1994). Tour operators' role in the tourism distribution system: an Indonesian case study. Journal of International Consumer Marketing, 6(3-4), 161 - 179. https://doi.org/10.1300/J046v06n03_09

Gertner, R.K., \& Freire, J. (2018). Impact of place brand names on destination image. International Journal of Leisure and Tourism Marketing, 6(1), 39-50.

Gunn, C.A. (1988). Vacationscape: Designing Tourist Regions. Van Nostrand Reinhold. ISBN: 9780442226794.

Hanusch, F. (2009). Taking travel journalism seriously: Suggestions for scientific inquiry into a neglected genre. In Communication, creativity and global citizenship: Refereed proceedings of the Australian and New Zealand communication association conference 2009, 623-636, Australian and New Zealand Communication Association.

Hanusch, F. (2010). The dimensions of travel journalism. Journalism Studies, 11(1), 68-82. https://doi.org/10.1080/14616700903290569

Hanusch, F. (2012). Broadening the focus: the case for lifestyle journalism as a field of scholarly inquiry. Journalism Practice, 6 (1), 211. https://doi.org/10.1080/17512786.2011.622895

Hanusch, F. (2012a). A profile of Australian journalist's professional views and ethical standards. Journalism, 13 (5), 668-686. https://doi.org/10.1177/1464884911398338 
Lewis, J.M.W., Williams, A., Franklin, R.A., Thomas, J., \& Mosdell, N.A. (2008). The quality and independence of British journalism: Tracking the changes over 20 years. http://www.mediawise.org.uk/wp-content/uploads/2011/03/Quality-Independenceof-British-Journalism.pdf

Lincoln, Y.S., \& Guba, E. (1985). Naturalistic Inquiry, SAGE Publications, Beverly Hills, CA.

Merriam, S.B. (1988). Case study research in education: A qualitative approach. Jossey-Bass.

McGaurr, L. (2010). Travel journalism and environment conflict. Journalism Studies, 11(1), 50-67. https://doi.org/10.1080/14616700903068924

McGaurr, L. (2012). The devil may care. Travel journalism, cosmopolitan concern, politics and the brand. Journalism Practice, 6(1), 4258. https://doi.org/10.1080/17512786.2011.622907

McGaurr, L. (2013). Travel journalism, cosmopolitan concern and the place-branded environment. Doctoral dissertation, University of Tasmania.

McGaurr, L. (2015). Environmental Communication and Travel Journalism, Conflict and Concern. London: Routledge. https://doi.org/ $10.4324 / 9781315773902$

Miles, M.B., \& Huberman, A.M. (1994). Qualitative data analysis: An expanded sourcebook. sage.

Moss, C. (2008). Travel Journalism: The road to nowhere. British Journalism Review, 19 (1), 33-40. https://doi.org/10.1177/0956474808090193

Moutinho, L., Rate, S., \& Ballantyne, R. (2013). Futurecast: an exploration of key emerging megatrends in the tourism arena. Trends in European Tourism Planning and Organisation. Bristol/Buffalo/Toronto: Channel View Publications, 313-325.

Munro, J., \& Richards, B. (2011). The digital challenge. In Destination brands: Managing Place Reputation, 3rd ed., N. Morgan, A. Pritchard, A., \& R. Pride, 141-154. Oxford: Butterworth-Heinemann.

Ninemeier, J.D., \& Perdue, J. (2005). Hospitality Operations: Careers in the World's Greatest Industry. Upper Saddle River, NJ: Prentice-Hall.

Oliveira, E., \& Panyik, E. (2015). Content, context and co-creation: Digital challenges in destination branding with references to Portugal as a tourist destination. Journal of Vacation Marketing, 21(1), 53-74. https://doi.org/10.1177/1356766714544235

Page, S. (2009). Tourism Management. An Introduction. 4th ed. Oxford: Elsevier Ltd. https://doi.org/10.4324/9781315768267

Pan, S., Santos, C., \& Kim, S. (2017). Promoting Tourism, Projecting Power: The Role of Television Commercials. Journal of Travel and Tourism Marketing, 34(2), 192-208. https://doi.org/10.1080/10548408.2016.1156610

Pasquinelli, C., \& Trunfio, M. (2020). Overtouristified cities: an online news media narrative analysis. Journal of Sustainable Tourism, 28(11), 1805-1824. https://doi.org/10.1080/09669582.2020.1760871

Patton, M.Q. (1990). Qualitative evaluation and research methods. SAGE Publications, inc.

Strauss, A., \& Corbin, J. (1998). Basics of qualitative research techniques, 1-312, Thousand oaks, CA: Sage publications.

Pike, S., \& Page, S. (2014). Destination marketing organizations and destination marketing: A narrative analysis of the literature. Tourism Management, 41, 202-227. https://doi.org/10.1016/j.tourman.2013.09.009

Pike, S., Jin, H.S., \& Kotsi, F. (2019). There is nothing so practical as good theory for tracking destination image over time. Journal of Destination Marketing and Management, 14. https://doi.org/10.1016/j.jdmm.2019.100387

Pirolli, B. (2017). Travel Journalists and Professional Identity. Journalism Practice, 11(6), 740-759. https://doi.org/10.1080/17512786.2016.1193821

Pirolli, B. (2019). Travel Journalism. Informing Tourists in the Digital Age. London: Routledge. https://doi.org/10.4324/9781315110738

Pokazanyeva, I. (2013). Aspects of Travel Journalism. Современная медиасреда: функииональные, тематические, профессиональные аспекты: межвуз. сб. науч. работ студентов и аспирантов. СПб. 199-205

Pulizzi, J. (2012). The rise of storytelling as the new marketing. Publishing research quarterly, 28(2), 116-123. https://doi.org/ $10.1007 / \mathrm{s} 12109-012-9264-5$

Reynolds, W.H. (1965). The role of the consumer in image building. California Management Review, 7(3), 69-76. https://doi.org/10.2307/41165634

Rapley, T.J. (2001). The art (fulness) of open-ended interviewing: some considerations on analysing interviews. Qualitative research, 1(3), 303-323. https://doi.org/10.1177/146879410100100303

Rosenkranz, T. (2015). Becoming entrepreneurial: crisis, ethics and marketization in the field of travel journalism. Poetics, 1-12. https://doi.org/10.1016/j.poetic.2015.09.003

Santos, C. (2004). Perception and interpretation of leisure travel articles. Leisure Sciences 26, 393-410. https://doi.org/ $10.1080 / 01490400490502462$

Schellhorn, M., \& Perkins, H.C. (2004). The stuff of which dreams are made: Representations of the South Sea in German-language tourist brochures. Current Issues in Tourism, 7(2), 95-133. https://doi.org/10.1080/13683500408667975

Shiner, M., \& Newburn, T. (1997). Definitely, maybe not? The normalisation of recreational drug use amongst young people. Sociology, 31(3), 511-529. https://doi.org/10.1177/0038038597031003008

Wolcott, H.F. (1990). Making a study "more ethnographic". Journal of contemporary Ethnography, 19(1), 44-72. https://doi.org/ $10.1177 / 089124190019001003$

Zenker, S., Eggers, F., \& Farsky, M. (2013). Putting a price tag on cities: Insights into the competitive environment of places. Cities, 30, 133-139. https://doi.org/10.1016/j.cities.2012.02.002

Zerfass, A., Verci, D., \& Wiesenberg, M. (2016). The dawn of a new golden age for media relations? How PR professionals interact with the mass media and use new collaboration practices. Public Relations Review, 42(4), 499-508. https://doi.org/10.1016/j.pubrev.2016.03.005

*** UNWTO (2021). 2020, Worst Year in Tourism History with 1 Billion Fewer International Arrivals, assessed February $5^{\text {th }} 2021$ https://www.unwto.org/taxonomy/term/347

*** WTTC (2019). Economic Impact Reports'. https://wttc.org/Research/Economic-Impact, assessed on 5 February 2021.

Article history: Received: 02.05.2021 Revised: 06.08.2021 Accepted: 06.09.2021 Available online: 30.09 .2021 